\title{
INFLUENCE OF LEADERSHIP TRAINING LEVEL III, CREATIVITY AND COMMITMENT TO PERFORMANCE OF EMPLOYEES DUTIES OF HEALTH MINISTRY OF THE REPUBLIC OF INDONESIA
}

\author{
Haslinda Daulay \\ State University of jakarta \\ Email: haslindadaulay_im13s3@mahasiswa.unj.ac.id \\ Maruf Akbar \\ State University of Jakarta \\ Email: marufakbar@unj.ac.id \\ Mansyur Ramly \\ State University of Jakarta \\ Email: mansyurramly@unj.ac.id
}

\begin{abstract}
The purpose of this study was to study the effect of level III leadership training, creativity and task commitment on employee performance. The research process was carried out at the Ministry of Health of the Republic of Indonesia using a case study method. The study sample was 168 employees of the Ministry of Health of the Republic of Indonesia who were selected by simple random sampling from 289 populations. The findings are: (1) there is a positive direct effect of level III leadership training on employee performance, (2) there is a positive direct effect of creativity on employee performance, (3) there is a positive direct influence on task commitment to employee performance, (4) direct influence positive level III leadership training on creativity, (5) there is a positive direct influence on task commitment to creativity. Referring to these findings, researchers can conclude that employee performance is positively influenced by level III leadership training, creativity and task commitment. Therefore, to maintain employee performance, organizations must implement level III leadership training, creativity and task commitment. Finally, it was concluded that level III leadership training, creativity and task commitment must be considered in producing employee performance.
\end{abstract}

Keywords: Employee Performance, Level III Leadership Training, Creativity and Task Commitment

\section{INTRODUCTION}

The Ministry of Health was formed in order to assist the Indonesian President in organizing state governance in the health sector. In Presidential Regulation No. 35 of 2015 concerning the ministry of health it was stated that the task to the ministry of health was to organize governmental affairs in the health sector to assist the president in organizing state government.

Therefore, structuring the HR management system (human resources) of the apparatus which is the asset of the organization needs to be given top priority. Structural position is a position that shows the duty of responsibility, authority, and rights of an ASN in order to lead a unit of state organization. Echelon III officials in carrying out their duties have duties (duties and functions) which are regulated in the laws and regulations.

Human investment is the most important inventory for organizations whose purpose comes at one endpoint, namely that the organization has a number of qualified, disciplined, dedicated, loyal, perceptual, efficient, work effectiveness and work productivity can meet the needs of the organization, not only for the future now but for the future. Okky in his research concluded that human resource management needs to pay attention to motivation, training 
and employee competency because it will affect employee productivity both directly and indirectly will also influence the quality and productivity of the Institute. In his research, the influence of work competencies on employee productivity is very significant at $87.90 \%$ () (Satria \& Kuswara, 2013).

HR is a very important element in a company. Failure to manage HR can lead to disruption in achieving goals in the organization, both in performance, profit, and survival of the organization. This is because HRM regulates the workforce in the organization. HRM can also produce good performance in an organization by means of valuation, giving remuneration in each individual member according to his ability to work. As explained by Glinow that organizations are a group consisting of a group of people who work together to achieve a goal (Steve \& Glinow., 2010).

\section{LITERATURE REVIEW}

Performance management to develop employees who are effective in their work. When employees do not perform as they should, performance management seeks to improve their performance. For this reason, training is needed to improve their work. Effective training will benefit both the company, employees and the growth and maintenance of harmonious relationships between members of the organization. For organizations, training can increase organizational productivity, for employees, training that effectively increases their ability to solve work problems. As for fellow employees, effective training enables effective communication and a favorable climate for the growth of all employees (Kaswan \& Ahkyadi, 2015).

One aspect that influences employee performance is leadership, where leadership is a process to influence others to understand and agree with what needs to be done effectively. This is evident in the research conducted by Jaka Alit that the significant influence of leadership seen from direction, participation, communication, and leadership exemplary contribute positively to employee performance, both seen from the quality, quantity, cooperation, and responsibility in their work (Wiratama \& Sintaasih, 2013).

Research conducted by Elnaga, said that the main purpose of each training session is to add value to employee performance, therefore all types of businesses design training and development programs for their employees as a sustainable activity. The training objective is what employees will achieve after experiencing a training program. Some organizations plan and implement training programs for their employees without identifying goals and objectives and without knowing what will be learned, the skills and abilities that employees will learn at the end of the training program and whether they will be able to achieve performance targets on the job. Therefore, companies must design training programs with clear goals and objectives while taking into account the special needs of individuals and companies (Elnaga \& Imran, 2013).

In the personnel management system, echelon III officials play a very decisive role in describing the vision and mission of the agency into programs and leading subordinates and all stakeholders strategicto carry out these programs effectively and efficiently. This task requires him to have tactical leadership skills, namely the ability to describe the agency's vision and mission into agency programs and the ability to influence structural and functional officials under it, including stakeholders otherto implement these programs. In the sense that echelon III officials are required to have leadership competencies that are able to formulate the program and lead the realization of the program (Lembaga Administrasi Negara, 2013).

Creative problem solving approaches such asmaterial fish born, time management, presentation skills, TQM, and so on have been found to greatly help improve employee skills (Ghosh, Joshi, Satyawadi, \& Mukherjee, 2011). However, it is very unfortunate, training and development are more focused on the characteristics of the training participants (ability, motivation, training design, work environment, etc.) as predictors of the results of training, whereas one other important thing is the role of the trainer. It should be noted that interactions between participants and trainers (Harris et al., 2014). 
Lately psychologists and management have studied creativity in various domains, including the domain of organizational behavior. But finding a big challenge is because of the complexity of the problem of creativity itself, which starts from individual skills in the dynamics of organizational climate where employees work for a long time for projects that are very different from the results that vary in a number of dimensions. When trying to define the construct of creativity, the first difficulty found is that this concept covers a variety of different phenomena but is related to one another, namely: creative products, creative people, creative situations, creative processes and creative potential (Agnes \& Kormos, n.d.).

Amabile in its componential theory of creativity states that there are three components in problem solving skills, namely: (1). domain relevant skills include knowledge, expertise, intelligence, talent; (2). Creativity relevant process includes style, cognitive personality, risk taking, and new perspectives on problems; \& (3). intrinsic task motivation, motivation to do tasks or solve problems because they are interesting, challenging or satisfying and without extrinsic motivation; coupled with components outside the work environment is always called the social environment. Other factors that can stimulate creativity such as: freedom in carrying out work, collaborative work teams, supervisors who encourage the taking of new ideas, top management that supports innovation by recognizing the creative work itself (Zhou \& Shalley, 2008).

Creativity in determining the changes that need to be done is very important to note. Creativity and innovation are especially important at the time of the exchange session. Many organizations believe that creativity and innovation are the forerunners of success. Creativity can be used in all steps of rational decision making and whenever an individual or group tries to solve a problem, make a decision, or develop something new (Angelo \& R., 2014).

In today's competitive business environment, global competition forces companies to continue to look for ways to improve their services. Constantine, said that creativity is a topic that has inspired researchers to explain why certain individuals, teams or organizations formulate ideas, service processes or new / useful products. There are five things, namely: Climate organization, leadership style, organizational culture, structure \& system, and resources \& skills. Managers are responsible for coordinating, fostering, directing and controlling the creative activities of their employees towards achieving organizational goals both personally and in groups (Andriopoulos, 2010).

One of the organizational commitments to employees can be created by the leadership style applied in the organization. Leaders play a major role in influencing others, including the loyalty of their employees or people who are led so that from the people they lead arises a willingness, respect, obedience and trust in the leadership to carry out what is desired by the leader and the duties and objectives of the organization in order to be effective and efficient.

Mira \& Rhoaders almost simultaneously (Mira \& Margaretha, 2012) in their study concluded that servant leadership has a relationship and has a positive and significant effect on organizational commitment of $16.8 \%$, meaning that if the employee is tied to the organization, he will be committed to the organization and willing do the task beyond what is required of him. The emotional bond of employees with organizations is considered an important determinant of loyalty and dedication. Employees who are effectively committed are seen as having a sense of belonging to the organization, being involved in organizational activities, willingness to pursue organizational goals, and their desire to stay with the organization ((Mira \& Margaretha, 2012) \& (Rhoaders, Eisenberger, \& Armeli, 2011).

(Janoniene \& Endriulaitiene, 2014) states that many scientists and practitioners illustrate that organizational commitment is a desirable tool to bind employees strongly in an effort to increase organizational productivity and effectiveness. In some cases, organizational commitment can describe the social functions and personal functions of employees and the effective functioning of the organization. Affective commitment positively influences the professional efficacy of employees and reduces the possibility of fatigue (boredom) and withdrawal behavior. Then Morrow states that individuals who regard their work as a major 
aspect of life will not be able to underestimate the importance of their careers. Therefore the idea of work commitment is a unique and redundant component (Morrow, 1983).

Based on this explanation, researchers wanted to find out whether level III leadership training had succeeded in giving birth to alumni who were creative in responding to changes in their work units and committed to work so that the performance of the ministry of health was increasing in general. From 2014 to 2018 the performance of all education and training alumni has never been studied at the health ministry. Their spread throughout Indonesia is expected to help reduce morbidity in Indonesia. Thus researchers are interested in conducting research on "The Influence of Level III Leadership Training, Creativity, and Task Commitment on the Ministry of Health's Employee Performance".

This research generally aims to prove the influence of level III leadership training, creativity and task commitment on employee performance at the Indonesian Ministry of Health. In particular, this study aims to test whether or not there are: (1). direct influence of level III leadership training on employee performance; (2). direct influence of creativity on employee performance; (3). direct influence of task commitment on employee performance; (4). direct influence of level III leadership training on task commitment; (5). direct influence of level III leadership training on creativity.

\section{METHODOLOGY}

The place of research was conducted at the Indonesian Ministry of Health office. Time the research was conducted for approximately 5 months. This research is a quantitative study with a type of survey and a causal approach, data obtained by means of interviews and then analyzed by path analysis. There are 4 (four) variables to be examined. The four variables consisted of 3 (three) exogenous variables, among others: first, the level III leadership training variable (X1) using (Sinambela, 2018) theory and (Bernadin \& Russell, 2013) obtained indicators namely, training needs assessment, training program development and training program effectiveness; second, creativity (X2) using the theory of (Riyani, 2016) and (Stojanova, 2010) obtained indicators, namely, the authenticity of ideas, the smooth production of many ideas, the flexibility of guiding and elaboration; third, is task commitment variable (X3) taken from the theory of (Newstorm \& Davis, 2007) and (Kerr \& Kronborg, 2016). It can be concluded that the indicators are, active participation in the organization, working hard for the interests of the organization, involvement in organizational obligations, and being loyal to the organization. For employee performance variable (X4), namely endogenous variable, the indicators are obtained from (Gomes, 2003) and (Wibowo, 2016) theory, so that discipline, optimal program responsibility, cooperation between colleagues, work initiatives, and achievement of targets are obtained. This can be seen in the constellation of relationships between variables, as can be seen in the following figure:

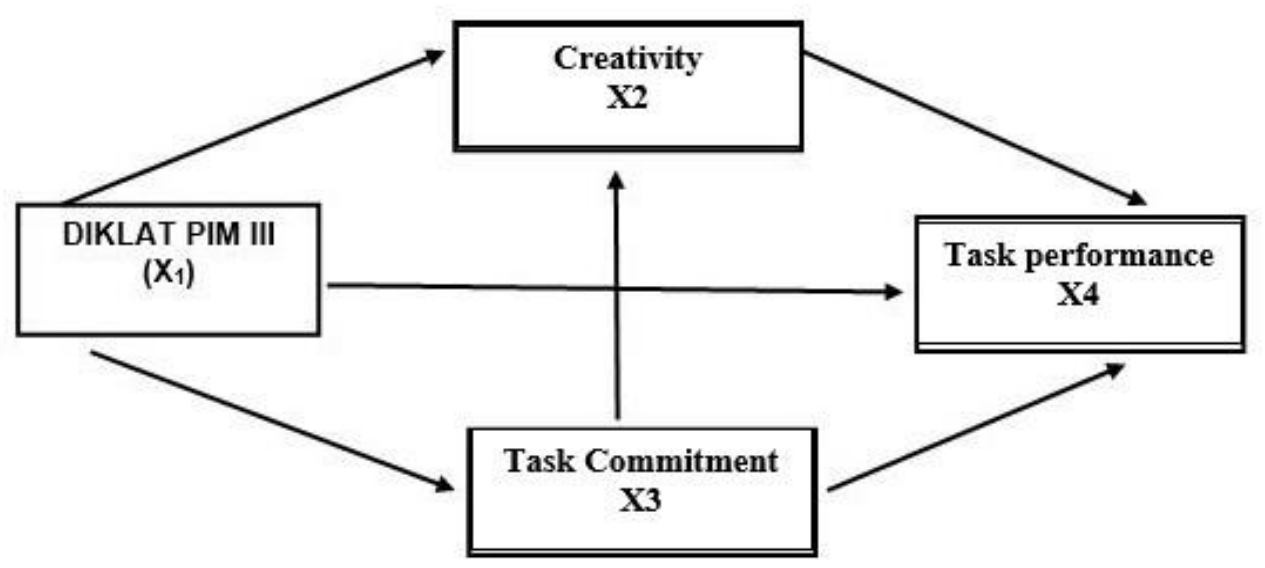

Figure 1 Constellation of Research Problems 
Population is the whole subject of research. Meanwhile Sugiyono said the population is a generalization area consisting of objects/subjects that have certain qualities and characteristics determined by researchers to be studied and then conclusions drawn (Sugiyono, 2015). In this study, the target population is employees of the Ministry of Health who have attended level III leadership training in 2014 to 2018 totaling 289 people.

Sampling of 168 people was done by using probability sampling techniques, namely techniques that provide equal opportunities for each element (member) of the population to be chosen as sample members. While the selection of samples with simple random methods, namely samples taken from the population randomly regardless of the strata that exist in that population. By providing equal opportunities to all members of the population to become members of the sample by following several random numbers. In sampling used Slovin formula (Umar, 1997).

\section{RESULT AND DISCUSSION}

Testing requirements for data analysis include: (1) Normality Test for Sample Estimation Error, (2) Linearity Test.

Based on data processing using SPSS 25, the normality test output is shown as shown in table 1 below.

Table 1

\section{Normality Test Results}

Tests of Normality

\begin{tabular}{|l|r|r|r|r|r|r|}
\hline & \multicolumn{3}{|c|}{ Kolmogorov-Smirnov $^{\text {a }}$} & \multicolumn{3}{c|}{ Shapiro-Wilk } \\
\cline { 2 - 7 } & Statistic & \multicolumn{1}{|c|}{$\mathrm{df}$} & \multicolumn{1}{c|}{ Sig. } & \multicolumn{1}{c|}{ Statistic } & \multicolumn{1}{c|}{ df } & \multicolumn{1}{c|}{ Sig. } \\
\hline X4 (Kinerja Pegawai) &, 065 & 168 &, 078 &, 983 & 168 &, 043 \\
X1 (Diklat Kepemimpinan &, 059 & 168 &, $200^{*}$ &, 984 & 168 &, 048 \\
Tingkat III) &, 051 & 168 &, $200^{*}$ &, 982 & 168 &, 028 \\
X2 (Kreativitas) &, 066 & 168 &, 070 &, 990 & 168 &, 261 \\
X3 (Komitmen Tugas) & & & & & \\
\hline
\end{tabular}

*. This is a lower bound of the true significance.

a. Lilliefors Significance Correction

From the above output we see in the Kolmogorov-Smirnov column and it can be seen that the significance value for employee performance is 0.078 , level III leadership training is 0.200 , creativity is 0.200 and task commitment is 0.070 . Because the significance of all variables is greater than 0.05 , it can be concluded that the population of employee performance data, level III leadership training, creativity and task commitment are normally distributed.

Based on the results of the aeritas test using SPSS 25 can be seen in the summary of the results of the calculation of the linearity test in table 2 below.

Table 2

Recapitulation of Linearity Test Calculation Results

\section{Linearity Test Linierity Test Results}

\begin{tabular}{ccc}
\hline $\mathrm{X}_{1}-\mathrm{X}_{4}$ & 0,000 & Linear \\
\hline $\mathrm{X}_{2}-\mathrm{X}_{4}$ & 0,000 & Linear \\
\hline $\mathrm{X}_{3}-\mathrm{X}_{4}$ & 0,000 & Linear \\
\hline $\mathrm{X}_{1}-\mathrm{X}_{3}$ & 0,000 & Linear \\
\hline $\mathrm{X}_{1}-\mathrm{X}_{2}$ & 0,000 & Linear \\
\hline $\mathrm{X}_{3}-\mathrm{X}_{2}$ & 0,000 & Linear \\
\hline
\end{tabular}


From the table above, it can be seen that the significance value in linearity is 0,000 . Because the significance is less than 0.05 , it can be concluded that between independent variables and dependent variables there is arelationship linear.

The summary of the calculation of direct effects can be summarized in the following table 4.25 .

Table 3

Results of Calculation of Direct Effects and Path Coefficients

\begin{tabular}{cccccc} 
No & Line & CoefficientLine & $\begin{array}{c}\mathbf{t}_{\text {count }} \\
\mathbf{Z}_{\text {count }}\end{array}$ & $\mathbf{t}_{\text {table }}$ & $\begin{array}{c}\text { Descripti } \\
\text { on }\end{array}$ \\
\hline 1 & $\mathrm{X}_{1}-\mathrm{X}_{4}$ & $\rho_{41}=0.272$ & 4,409 & 2,660 & $\begin{array}{c}\text { Significan } \\
\mathrm{t}\end{array}$ \\
\hline 1 & $\mathrm{X}_{2}-\mathrm{X}_{4}$ & $\rho_{42}=0.270$ & 4,108 & 2,660 & $\begin{array}{c}\text { Significan } \\
\mathrm{t}\end{array}$ \\
\hline 1 & $\mathrm{X}_{3}-\mathrm{X}_{4}$ & $\rho_{43}=0.350$ & 5,328 & 2,660 & $\begin{array}{c}\text { Significan } \\
\mathrm{t}\end{array}$ \\
\hline 1 & $\mathrm{X}_{1}-\mathrm{X}_{3}$ & $\rho_{31}=0.232$ & 3.079 & 1,974 & $\begin{array}{c}\text { Significan } \\
\mathrm{t}\end{array}$ \\
\hline 1 & $\mathrm{X}_{1}-\mathrm{X}_{2}$ & $\rho_{21}=0.241$ & 3,197 & 1,974 & $\begin{array}{c}\text { Significan } \\
\mathrm{t}\end{array}$ \\
\hline
\end{tabular}

Based on the results of the analysis and hypothesis testing shows that the six hypotheses proposed in this study are proven. This implies that in general in the environment of the Ministry of Health of the Republic of Indonesia, there is a direct influence: (1) level III leadership training on employee performance; (2) creativity on employee performance; (3) task commitment to employee performance; (4) level III leadership training on task commitment; (5) level III leadership training on creativity.

In detail, the discussion of the results of analysis and testing of research hypotheses is described as follows:

\section{Hypothesis Test Results Effect of Training Level III Leadership ( $\left.X_{1}\right)$ on Employee Performance $\left(\mathbf{X}_{4}\right)$}

Judging from the theory or concept of Level III Leadership Training is the intensity of activities carried out for improve the competence and professionalism of echelon III officials in the field of tasks embraced to achieve organizational goals. The aspects of level III leadership training must be managed well in an organization. Likewise with the Indonesian Ministry of Health as one of the ministries that manage health in Indonesia.

In this study it is in line with the hypothesis to prove level III leadership training has an effect on employee performance at the Indonesian Ministry of Health. From the results of verification research, it turns out level III leadership training has a positive direct effect on employee performance. This can be proven from hypothesis testing which produces $t_{\text {count }}$ of 4.409 greater than $t_{\text {table }}$ of 2.660 or can be expressed symbolically $t_{\text {count }} 4.409>t_{\text {table }} 2.660$. This shows that employee performance can be improved by strengthening PIM III Education and training.

Training is a development of human resources specifically designed to develop knowledge, skills, competencies, attitudes and behavior of employees in order to improve the 
performance of employees to carry out their work they are doing now. Today's training needs not only focus on technical training, but also about managerial, soft skills needed for all employees at every level of office. This is due to the demands of community service and the development of science and technology that continues to grow (Wirawan, 2015).

Based on the results of hypothesis testing, that the effect of level III leadership training on employee performance is 0.272 or $27.2 \%$. This is supported by the opinions of several experts as outlined in the theoretical framework represented by research (Ibrahim, Boerhannoeddin, \& Bakare, 2017) with the title "The effect of soft skills and methodology training on employee performance". The results of the study stated that there was a positive relationship between training (soft skills and training methodology) and performance.

Of the three indicators of level III leadership training, there is 1 indicator that is still low (the average score is less than 4), which is an indicator of training needs assessment with an indicator score of 2.46. These indicators need to be improved (i.e. widyaiswara competencies, resource persons, training materials) because with this increase in indicators, they can certainly contribute to improving employee performance.

Regarding training materials, there is still a lot to be improved, because the end of education and training is a change project that will be an alumni competency to always be carried if placed anywhere. The success of the resulting change project can not be separated from the role of the leader / boss to motivate and guide the training participants in the constituent project changes to carry out their duties. The role of leaders in the guidance and implementation of change projects encourages training participants to work to meet the standards set. Through the project changes that have been made, the leader will be easier to guide, supervise, and encourage employees whether their work does not meet the requirements of the standard.

While the indicators are good, namely the indicators of the development of training programs and indicators of the effectiveness of the education and training program, leaders at the Indonesian Ministry of Health need to take care of them so that these indicators are maintained.

Based on empirical evidence, the findings of this study indicate that level III leadership training is one of the most important variables and has a direct effect on employee performance variables.

\section{Hypothesis Test Results Effect of Creativity $\left(\mathbf{X}_{2}\right)$ on Employee Performance $\left(\mathbf{X}_{4}\right)$}

Creativity is a way / action of work that is shown by someone to perform / present tasks and reporting in accordance with their responsibilities more effectively and efficiently to achieve targets / results of work. Good creativity must be managed well in an organization. Likewise with the organization of the Ministry of Health of the Republic of Indonesia, the ministry that takes care of these health issues.

In this study, it is in line with the hypothesis to prove that creativity influences employee performance at the Indonesian Ministry of Health. From the results of verification research, it turns out that creativity has a positive direct effect on employee performance. This can be proven from hypothesis testing which produces $t_{\text {count }}$ of 4.108 greater than $t_{\text {table }}$ of 2.660 or can be expressed symbolically $t_{\text {count }} 4.108>t_{\text {table }} 2.660$.

Based on the results of hypothesis testing, that the influence of creativity on employee performance is 0.270 or $27 \%$. This is supported by the opinion of several experts as outlined in the theoretical framework represented by Stojanova which states that the higher the mastery of science and work skills, the more ideas or thoughts emitted. The higher the quality of a person, the more the quantity of work achieved (increasesproductivity). Creativity and productivity are forms of jointness in connection so as to form a whole between the process of implementing work and the variety of efforts undertaken to achieve results in accordance with predetermined expectations (Stojanova, 2010). The results of this study were also supported by research (Yoopetch, 2011) with the title "The Relationship of Employee Knowledge, Employee Creativity and Employee Performance: An Empirical Investigation of 
Hotel Industry in Thailand". The results showed that employee knowledge and employee creativity had a significant positive relationship with employee performance.

Of the four indicators of creativity, there are two indicators that need to be improved, namely the indicator of smooth production of many ideas with a score of indicator 2.06 and an elaboration indicator with an indicator score of 2.32 .

Both of these indicators need to be improved because with the increase in these indicators certainly can contribute to improving employee performance. While the indicators are good, namely the indicator of the authenticity of ideas and indicators of flexibility to guide, the leaders at the Indonesian Ministry of Health need to take care of them so that these indicators are maintained well.

Associated with reality in the field, researchers argue that although it has a mechanism in managing creativity as stated by the experts above including in taking policies related to creativity that consider the perspective of employees but in its implementation there are still gaps as shown in the description of research data. Evidence that the Ministry of Health of the Republic of Indonesia has managed personality well, the Ministry of Health of the Republic of Indonesia gives freedom to its employees to work and think creatively, receive advice and input from employees in meetings held by the Indonesian Ministry of Health.

Based on empirical evidence, these findings indicate that creativity is a very important variable and has a direct effect on employee performance variables.

\section{Hypothesis Test Results Effect of Task Commitment $\left(\mathbf{X}_{3}\right)$ on Employee Performance $\left(\mathbf{X}_{4}\right)$}

Commitment tasks in principle are strong attachments from individuals to continue to work consistently with the organization and intend to maintain membership loyalty by directing all of their abilities to succeed organizational goals. Factors that support the commitment of the task must be managed properly in an organization. Likewise with the organization of the Indonesian Ministry of Health as one of the ministries in the government cabinet that takes care of health in Indonesia.

In this study, it is in line with the hypothesis to prove the commitment of duty influences the performance of employees at the Indonesian Ministry of Health. From the results of verification research, it turns out that task commitment has a positive direct effect on employee performance. This can be proven from hypothesis testing which produces $t_{\text {count }}$ equal to 5.328 greater than $t_{\text {table }}$ equal to 2.660 or can be expressed symbolically $t_{\text {count }} 5.328>$ $\mathrm{t}_{\text {table }} 2.660$.

Based on the results of hypothesis testing, that the effect of task commitment on employee performance is 0.350 or $35.0 \%$. This is supported by the opinion of several experts as outlined in the theoretical framework represented by the Judge who stated that organizational commitment has an effect on employee performance because employees who have a high level of commitment to the organization tend to have a high attitude towards, love and obligation to the organization. this will motivate to complete the work that is charged in an adult, calm, and responsible by using all the physical and psychological abilities it has. So to improve employee performance needs to improve organizational culture and organizational commitment (Hakim, 2015). The results of this study are also reinforced by research conducted by (Sani, 2013) with the title "Role of Procedural Justice, Organizational Commitment and Job Satisfaction on Job Performance: The Mediating Effects of Organizational Citizenship Behavior". The results showed that procedural justice and organizational commitment had a positive effect on Organizational Citizenship Behavior. Organizational commitment has a positive effect on job performance.

Of the five task commitment variable indicators $\left(\mathrm{X}_{3}\right)$ there are 2 indicators that are still low (the average score is less than 4), namely indicators of involvement in organizational obligations with indicator score 3.47 and indicators are obedient to the organization with an indicator score of 3.35 . Both of these indicators need to be improved because with the increase in these indicators certainly can contribute to improving employee performance. 
While the indicators that are good, namely indicators of active participation in the organization, indicators working hard for the benefit of the organization and loyal indicators for the organization, leaders at the Indonesian Ministry of Health need to take care of them so that these indicators are maintained well.

Associated with reality in the field, researchers argue that even though the Indonesian Ministry of Health already has a mechanism for managing task commitments as stated by the experts above including in taking policies related to task commitments that consider the perspective of employees but in implementation there are still gaps as shown in the description research data. Evidence that the Ministry of Health of the Republic of Indonesia has managed the task commitment well, the Ministry of Health of the Republic of Indonesia in assessing the performance of its employees has included factors related to task commitment when assessing the performance of its employees.

Based on empirical evidence, these findings indicate that task commitment is one of the most important variables and has a direct effect on employee performance variables.

From the description of the theory above and based on empirical evidence carried out in this study, it is evident that task commitment has a positive direct effect on employee performance.

\section{Hypothesis Test Results Effect of Training Level III Leadership $\left(X_{1}\right)$ on Task Commitment $\left(\mathbf{X}_{3}\right)$}

Level III Leadership Training is basically the intensity of activities carried out to improve the competence and professionalism of echelon III officials in the field of tasks embraced to achieve organizational goals . The aspects of level III leadership training must be managed well in an organization. Likewise with the Indonesian Ministry of Health as one of the ministries that manage health in Indonesia.

In this study in line with the hypothesis to prove level III leadership training has an effect on task commitment in the Ministry of Health of the Republic of Indonesia. From the results of verification research, it turns out level III leadership training has a positive direct effect on task commitment. This can be proven from hypothesis testing which produces $t_{\text {count }}$ of 2.655 greater than $t_{\text {table }}$ of 1.650 or can be expressed symbolically $t_{\text {arithmetic }} 2.655>t_{\text {table }} 1,650$.

Based on the results of hypothesis testing, that the effect of level III leadership training on task commitment is 0.232 or $23.2 \%$. This is supported by the opinions of several experts as outlined in the theoretical framework represented by research (Inanlou \& Ahn, 2017) with the title "The Effect of Organizational Culture on Employee Commitments: A Mediating Role of Human Resource Development in Korean Firms". The results of this study found that organizational culture, in particular, was defined as better communication between superiors and subordinates, trust, and the climate of innovation, positively related to organizational commitment. In addition, company investment in HRD or employee participation in HRD plays a mediating role in influencing the relationship between organizational culture and organizational commitment. Therefore, organizational culture is an important factor for increasing workers 'motivation through participation in HR training programs, thereby increasing workers' commitment.

Of the three indicators of level III leadership training, there is 1 indicator that is still low (the average score is less than 4), which is an indicator of training needs assessment with an indicator score of 2.46. This indicator needs to be improved because with the increase in these indicators it can certainly contribute to increasing task commitment. While the indicators are good, namely the indicators of the development of training programs and indicators of the effectiveness of the education and training program, leaders at the Indonesian Ministry of Health need to take care of them so that these indicators are maintained.

Based on empirical evidence, the findings of this study indicate that level III leadership training is one of the most important variables and has a direct effect on task commitment variables. 


\section{Hypothesis Test Results Influence Level III Education Training $\left(\mathbf{X}_{1}\right)$ on Creativity $\left(\mathbf{X}_{2}\right)$}

Based on the theory or concept, Level III Leadership Training is basically the intensity of activities carried out to improve the competence and professionalism of echelon III officials in the field of tasks embraced to achieve organizational goals. The aspects of level III leadership training must be managed well in an organization. Likewise with the Indonesian Ministry of Health as one of the ministries that manage health in Indonesia.

In this study in line with the hypothesis to prove level III leadership training has an effect on creativity in the Indonesian Ministry of Health. From the results of verification research, it turns out level III leadership training has a positive direct effect on creativity. This can be proven from hypothesis testing which produces $t_{\text {count }}$ equal to 2.536 greater than $t_{\text {table }}$ equal to 1.650 or can be expressed symbolically $t_{\text {count }} 2.536>t_{\text {table }} 1.650$.

Based on the results of hypothesis testing, the effect of level III leadership training on creativity is 0.241 or $24.1 \%$. This is supported by the opinion of several experts as outlined in the theoretical framework represented by Dessler, which states that training means giving employees a new skill they currently need to do their jobs. In any case, training is the hallmark of good management, and this is a task managers always ignore. In future organizational changes, of course, a manager as the challenger must understand the details of the 8-step process to lead the following organizational changes. Among other things is to build a sense of urgency. This sense of urgency often requires creativity. For example, the CEO might provide an (fictitious) analyst report to the executive that describes the imminent death of the company, therefore employees need to be trained immediately (Dessler, 2011). This is in line with the research (Lourenco \& Jayawarna, 2011) with the title "Enterprise Education: The Effect of Creativity on Training Outcomes". Overall, the results of this study mostly agree with the TPB (theory of planned behavior) as applied to entrepreneurship and suggest the perception of creativity of trainees as a driver to improve study habits among newborn entrepreneurs.

Of the three indicators of level III leadership training, there is 1 indicator that is still low (the average score is less than 4), which is an indicator of training needs assessment with an indicator score of 2.46. This indicator needs to be improved because with the increase in these indicators it can certainly contribute to increasing creativity. While the indicators are good, namely the indicators of the development of training programs and indicators of the effectiveness of the education and training program, leaders at the Indonesian Ministry of Health need to take care of them so that these indicators are maintained.

Based on empirical evidence, the findings of this study indicate that level III leadership training is one of the most important variables and has a direct effect on the creativity variable.

\section{CONCLUSION}

Based on the analysis above, the findings in this study are as follows: There is a positive direct influence level III leadership training on employee performance, meaning that if level III leadership training increases, it is predicted that employee performance will also increase; There is a positive direct effect of creativity on employee performance, meaning that if creativity increases, it is predicted that employee performance will also increase; There is a positive direct effect on task commitment to employee performance, meaning that if task commitment increases, it is predicted that employee performance will also increase; There is a positive direct influence level III leadership training on task commitment, meaning that if level III leadership training increases, it is predicted that task commitment will also increase; There is a positive direct influence level III leadership training on creativity, meaning that if level III leadership training increases, it is predicted that creativity will also increase. 


\section{REFERENCES}

Agnes, A., \& Kormos, J. (n.d.). Creativity and Narrative Task Performance: An Exploratory Study. Eötvös Loránd University, Budapest, 1-32.

Andriopoulos, C. (2010). Determinants of organisational creativity: a literature review Determinants of organisational creativity: a literature review. Management Decision, 39(10), 834-841.

Angelo, K., \& R., K. (2014). Perilaku Organisasi (Buku 2). Salemba Empat.

Bernadin, H. J., \& Russell, J. E. A. (2013). Human Resources Management, An Experiental. New York: Mc Grow Hill.

Dessler, G. (2011). Human Resource Management (12 th edit). Florida International University: Pearson Education Limited.

Elnaga, A., \& Imran, A. (2013). The Effect of Training on Employee Performance. European Journal of Business and Management, 5(4), 137-147. https://doi.org/10.2991/gecss14.2014 .90

Gomes, F. C. (2003). Manajemen Sumber Daya Manusia. Yogyakarta: Andi Offset.

Hakim, A. (2015). Effect of Organizational Culture, Otganizational Comittment to Performance: Study In Hospital Of District South Konawe Of Southeast Sulawesi. The International Journal Of Engineering and Science (IJES), 4(5), 33-41.

Harris, T. B., Chung, W., Hutchins, H. M., Chiaburu, D. S., Harris, T. B., \& Chung, W. (2014). Do trainer style and learner orientation predict training outcomes? Journal of Workplace Learning, 26(5), 331-344. https://doi.org/10.1108/JWL-05-2013-0031

Ibrahim, R., Boerhannoeddin, A., \& Bakare, K. K. (2017). The effect of soft skills and training methodology on employee performance. European Journal of Training and Development, 41(4), 388-406. https://doi.org/10.1108/EJTD-08-2016-0066

Inanlou, Z., \& Ahn, J.-Y. (2017). The Effect Of Organizational Culture On Employee Commitment: A Mediating Role Of Human Resource Development In Korea Firm. The Journal Of Applied Business Reserch, 33(1), 87-94.

Janoniene, G. G., \& Endriulaitiene, A. (2014). Employees' Organizational Commitment: Its Negative Aspects for Organizations. Procedia - Social and Behavioral Sciences, 140, 558-564. https://doi.org/10.1016/j.sbspro.2014.04.470

Kaswan, \& Ahkyadi, A. S. (2015). Pengembangan Sumber Daya Manusia Dari Konsepsi, Paradigma, dan Fungsi Sampai Aplikasi.

Kerr, B. A., \& Kronborg, L. (2016). Editorial: Gifted and Talented International. Gifted and Talented International, 30(1-2), 1-5. https://doi.org/10.1080/15332276.2015.1137449

Lembaga Administrasi Negara. (2013). Peraturan Kepala Lembaga Administrasi Negara Nomor 12 Tahun 2013.

Mira, W. S., \& Margaretha, M. (2012). Pengaruh Servant Leadership Terhadap Komitmen Organisasi Dan Organization Citizenship Behavior. Jurnal Manajemen, 11(2), 99-116.

Morrow, P. C. (1983). Redundancy in Organizational Work The Commitment. The Academy of Management Review, 8(3), 486-500.

Newstorm, J., \& Davis, K. (2007). Organization Behavior, Human Behavior at Work. Boston: McGrow Hill Inc.

Rhoaders, L., Eisenberger, R., \& Armeli, S. (2011). Affective Commitment To The Organization: The Contribution of Perceived Organizational Support. Journal of Applied Psychology, 86(5), 825-836.

Riyani, B. P. D. (2016). Kreativitas \& Innovasi Di Tempat Kerja. Jakarta: Atma Jaya.

Sani, A. (2013). Role of Procedural Justice, Organizational Commitment and Job Satisfaction on job Performance: The Mediating Effects of Organizational Citizenship Behavior. International Journal of Business and Management, 8(15), 57-67. https://doi.org/10.5539/ijbm.v8n15p57

Satria, R. O., \& Kuswara, A. (2013). Pengaruh Motivasi dan Pelatihan Terhadap Kompetensi Kerja Serta Implikasinya Pada Produktivitas Pegawai Dinas Perhubungan Kota 
Bandung, 7(2), 74-83.

Sinambela, L. P. (2018). Manajemen Sumber Daya Manusia, Membangun Tim Kerja yang Solid Untuk Meningkatkan Kinerja. Jakrta: Bumi Aksara.

Steve, L. M., \& Glinow., V. (2010). Organization Behavior Emerging Knowledge and Prctice for The Real Word"e (5th ed.). New York: McGrow-Hill Irwin.

Stojanova, B. (2010). Development of creativity as a basic task of the modern educational system. Procedia - Social and Behavioral Sciences, 2(2), 3395-3400. https://doi.org/10.1016/j.sbspro.2010.03.522

Sugiyono. (2015). Metode Penelitian Manajemen Kuantitatif, Kualitatif, dan $R \& D$. Bandung: Alfabeta.

Umar, H. (1997). Riset Sumber Daya Manusia dalam Organisasi. Jakarta: Gramedia Pustaka Utama.

Wibowo. (2016). Manajemen Kinerja (Edisi Keli). Jakarta: Raja Grafindo Persada.

Wiratama, I. N. J. A., \& Sintaasih, D. K. (2013). Pengaruh Kepemimpinan, Diklat, dan Disiplin Kerja Terhadap Kinerja Karyawan PDAM Tirta Mangutama Kabupaten Badung. Jurnal Manajemen, Strategi Bisnis, Dan Kewirausahaan, 7(2), 126-134.

Wirawan. (2015). Manajemen Sumber Daya Manusia Indonesia. Jakarta: Raja Grafindo Persada.

Yoopetch, C. (2011). The Relationship of Employee Knowledge, Employee Creativity and Employee Performance: An Empirical Investigation of Hotel Industry in Thailand. The Asian Business and Management Conference, 284-295. Retrieved from http://iafor.org/acll_proceedings.html

Zhou, J., \& Shalley, C. E. (2008). Handbooks of Organizational Creativity (Vol. 91). New York: Taylor \& Francis Group LLC. 